\title{
Physical-Chemical Characteristic and Trophic Status of Some Small Lakes in Ciliwung Watershed, West Java Indonesia
}

\author{
Siti Aisyah $^{\mathrm{a}, *}$, Sulastri a, Rahmi Dina ${ }^{\text {a }}$, Mey Ristanti Widoretno ${ }^{\mathrm{a}}$ \\ ${ }^{a}$ Research Center for Limnology, National Research and Innovation Agency, Republic of Indonesia (BRIN); \\ Cibinong Science Center, Jalan Raya Bogor, Km. 46, Cibinong 16911 \\ *E-mail: iis@limnologi.lipi.go.id
}

\begin{abstract}
Small lakes are important freshwater resources to support the quality of human life. However, small lakes in the watershed are becoming threatened ecosystems because of increasing land-use changes and anthropogenic activity. The study aimed to determine characteristic physical-chemical parameters and trophic status some small lake in Ciliwung Watershed to support the sustainable management of small lakes in the Ciliwung watershed in preventing eutrophication effects. The data was collected in April and June 2021. Measurement and analysis of water quality parameters were conducted by insitu and Laboratory. Some parameters were not in accordance with the Government Regulation number 22/2021 for class II water quality criteria (WQC), including TSS $\left(>50 \mathrm{mg} . \mathrm{L}^{-1}\right)$., TP $\left(>0.03 \mathrm{mg} . \mathrm{L}^{-1}\right), \mathrm{COD}\left(>25 \mathrm{mg} . \mathrm{L}^{-1}\right)$ and DO ( $<3 \mathrm{mg} . \mathrm{L}^{-1}$ ), especially for Lake Sunter and Lake Cincin.There are two groups of lakes based on water quality and trophic status. Lake Telaga Warna Lake Cikaret, and Lake Cilodong were classified as eutrophic while lake Sunter and Lake Cincin were classified as hypereutrophic lake Lake Telaga Warna, Lake Cikaret, and Lake Cilodong, located at the upper and middle watershed, are eutrophic, characterized by deeper bottom and higher Secchi depth. At the lower watershed, Lake Sunter and Lake Cincin are hypereutrophic characterized by higher nutrients (TN and TP), COD, temperature, conductivity, salinity, and TDS. The downstream area was a densely populated area that contributed high pollution from upstream and middle of Ciliwung watershed.
\end{abstract}

Keywords: Characteristic, Ciliwung, physical-chemical, small lakes

\section{INTRODUCTION}

Assessment of surface water quality in lakes, rivers, and reservoirs is a key issue for environmental monitoring and management. Freshwater is a crucial resource for the survival of human life (Ladwig et al., 2018). However, freshwater ecosystems are facing threats due to anthropogenic activities. Waste disposal from domestic sources, agricultural runoff, aquaculture effluents, and tourism industry waste have deteriorated water sources, including the lakes. This phenomenon impairs the freshwater ecosystem, including aquatic life. In addition, the rapid growth of population and community development has worsened the water quality. Nutrient enrichment of water bodies is a primary

OMLI 2021 cause of eutrophication (Sinha et al., 2017). Effects of eutrophication on the environment may have consequences for animal and human health (WHO, 2002).

Generally, small lakes have small volume and size with an average depth of 3 to $5 \mathrm{~m}$ or less, which cause unstable hydrological balance and is sensitive to human impacts activities as increasing of nitrogen and phosphorus load from the watershed (Nesseli, 2008). Therefore, small lakes area tends to have high nutrient load and sensitive to the pollution and eutrophication. In Indonesia, especially West Java, small lakes have many functions, including flood control, irrigation, tourism, domestic water, and fisheries. However, they also play an essential role in conserving water resources, groundwater balance, and biodiversity 
(Henny and Meutia, 2013; Wakhid et al., 2020). There are over 200 small lakes around Jakarta, Bogor, Depok, Tangerang, and Bekasi (Jabodetabek) areas, situated at the Ciliwung watershed. Ciliwung River flows across through the regions within the megacity of Bogor, Depok, and Jakarta. Therefore, the impact of urban development in the surrounding Ciliwung watershed on small lakes is very vulnerable to environmental disturbances as eutrophication.

Previous studies reported that urban lakes in megacity Jakarta were at high risk of disappearing due to land-use change, sedimentation, eutrophication, and water pollution (Henny and Meutia, 2014). Among of pollution problems of urban lakes in the megacity, Jakarta is cyanobacteria blooms (Prihantini et al., 2008). In eutrophic conditions, the excessive amount of organic matter and algal blooms increase toxic substances and the development of foul odors and tastes (Yu et al., 2016). In addition, the increase of alga biomass causes low oxygen concentration in the waters, leading to the mortality of aquatic organisms and reducing the quality of water for human consumption and poses a greater risk on human health (Dokulil and Teubner, 2011; Chorus et al., 2000).

Eutrophication has multidimensional consequences related to the ecosystem's water quality, human health, and economic and social impact (Hwang, 2020), as occurred in Lake Maninjau, West Sumatera, Indonesia (Sulastri, 2002). Therefore, understanding, efficient assessment, and control of eutrophication are essential (Hwang, 2020).

Although eutrophication has been recognized, control of eutrophication remains the problem in managing megacity urban lakes. Previous studies reported that the loss and reducing Jakarta megacity urban lakes (Jabodetabek) indicated a lack of attention and management (Henny and Meutia, 2014). Lack of awareness and understanding of the eutrophication effect related to ecosystem, human health, and economic risks may also cause the policy not fully implemented in resolving the eutrophication problem in urban lakes. The study is aimed to determine characteristic physical-chemical parameters and trophic status some small lake in Ciliwung
Watershed to support the sustainable management of small lakes in the Ciliwung watershed in preventing eutrophication effects.

\section{METHODS}

\section{Study area}

The study was conducted in April and June 2021. The research area is in Lake Telaga Warna, Lake Cikaret, Lake Cilodong, Lake Sunter, and Lake Cincin, located at the Ciliwung watershed in West Java, Indonesia (Figure 1). Lake Telaga Warna and Lake Cikaret are situated in Bogor Regency, at the upstream and middle parts of the Ciliwung watershed, respectively. Telaga Warna is a conservation area used for tourism with the surface area, and the maximum depth is $5 \mathrm{Ha}$ and $15 \mathrm{~m}$, respectively (Supriyadi et al., 2015). Lake Cikaret is used for flood control and domestic water (agriculture and Fisheries) with the area (16,90 ha) (Supriyadi et al., 2015). Lake Sunter is used for flood control which consists of three lakes, namely South Lake Sunter with an area of 26 ha and average depth is $3.0 \mathrm{~m}$, East Lake Sunter with an area of 26 ha and average depth is $2.0 \mathrm{~m}$, and North Lake Sunter with the area 32 ha and average depth is $3.0 \mathrm{~m}$ (Public Work of DKI Jakarta, 2010).

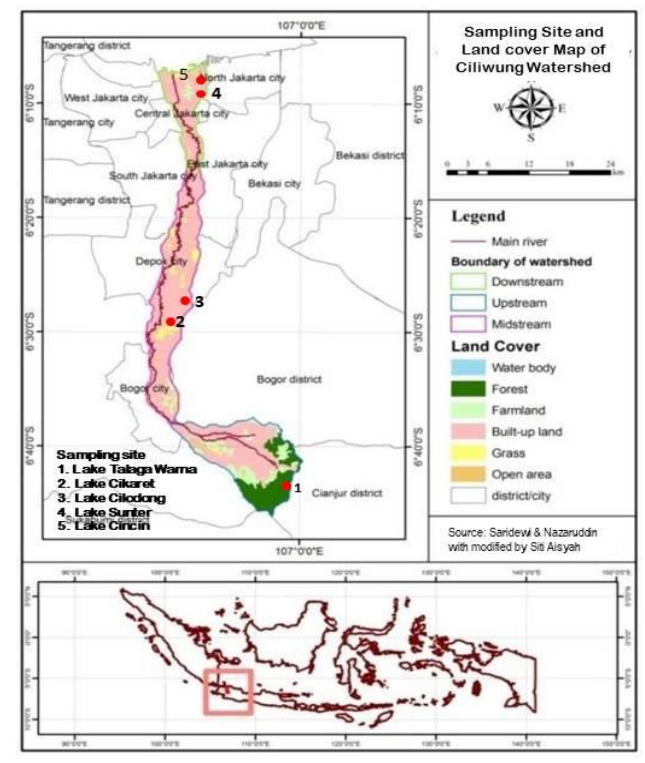

Figure 1. Map of research location

\section{Measurement and laboratory analysis}

The data was collected from the primary with some water quality parameters such as total nitrogen (TN), total phosphorus (TP) water 
temperature, $\mathrm{pH}$, Dissolved Oxygen (DO), and conductivity, total dissolved solids (TDS). Measurement and analysis method of the parameters described in Table 1.

Table 1. Methods of measurement and sample analysis

\begin{tabular}{|c|c|c|c|}
\hline No. & Parameter & Unit & Methode \\
\hline 1 & $\begin{array}{c}\text { Physical } \\
\text { Temperature }\end{array}$ & ${ }^{\circ} \mathrm{C}$ & $\begin{array}{l}\text { Water Quality } \\
\text { Checker YSI }\end{array}$ \\
\hline 2 & Conductivity & $\mathrm{mS} . \mathrm{cm}^{-1}$ & $\begin{array}{l}\text { Water Quality } \\
\text { Checker YSI }\end{array}$ \\
\hline 3 & TDS & g.L-1 & $\begin{array}{l}\text { Water Quality } \\
\text { Checker YSI }\end{array}$ \\
\hline 4 & TSS & $\mathrm{mg} \cdot \mathrm{L}^{-1}$ & Gravimetri \\
\hline 5 & Salinity & Ppt & $\begin{array}{l}\text { Water Quality } \\
\text { Checker YSI }\end{array}$ \\
\hline 6 & $\begin{array}{c}\text { Chemical } \\
\mathrm{pH}\end{array}$ & & $\begin{array}{l}\text { Water Quality } \\
\text { Checker YSI }\end{array}$ \\
\hline 7 & DO & $\mathrm{mg} \cdot \mathrm{L}^{-1}$ & $\begin{array}{l}\text { Water Quality } \\
\text { Checker YSI }\end{array}$ \\
\hline 8 & Total N & $\mathrm{mg} \cdot \mathrm{L}^{-1}$ & $\begin{array}{l}\text { Spectrophotomet } \\
\text { ry, Brucine }\end{array}$ \\
\hline 9 & Total P & $\mathrm{mg} \cdot \mathrm{L}^{-1}$ & $\begin{array}{l}\text { Spectrophotomet } \\
\text { ry, Ascorbic }\end{array}$ \\
\hline 10 & Chlorophyll-a & $\mu \mathrm{g} . \mathrm{L}^{-1}$ & $\begin{array}{l}\text { Acid } \\
\text { Spectrophotomet } \\
\text { ry, extracted in } \\
\text { Aceton }\end{array}$ \\
\hline 11 & COD & $\mathrm{mg} \cdot \mathrm{L}^{-1}$ & $\begin{array}{l}\text { Spectrophotomet } \\
\text { ry, Dichromate }\end{array}$ \\
\hline
\end{tabular}

Tabel 2. The physical-chemical properties of observed lakes

\begin{tabular}{|c|c|c|c|c|c|}
\hline Parameters & T. Warna & Cikaret & Cilodong & Sunter & Cincin \\
\hline $\begin{array}{l}\text { Water depth } \\
\text { (m) }\end{array}$ & 6.5 & 3.5 & & 1.5 & 1 \\
\hline $\begin{array}{l}\text { Secchi depth } \\
\text { (m) }\end{array}$ & 1 & 1.5 & & 0.3 & 0.3 \\
\hline $\begin{array}{l}\text { Temperature } \\
\left({ }^{\circ} \mathrm{C}\right)\end{array}$ & $20.5-21.5$ & $28.8-30.2$ & $30.5-30.7$ & $30.0-30.4$ & $29.5-33.5$ \\
\hline TSS (mg. $\left.\mathrm{L}^{-1}\right)$ & $6-7.5$ & $12-12.5$ & 16.4 & $53-84$ & $53-66$ \\
\hline $\begin{array}{l}\text { Conductivity } \\
\left(\mathrm{mS} \mathrm{cm}^{-1}\right)\end{array}$ & $0.034-0.064$ & $0.119-0.132$ & 0.107 & $0.456-0.695$ & $0.753-0.772$ \\
\hline TDS (g.L L $\left.^{-1}\right)$ & $0.023-0.037$ & $0.077-0.086$ & 0.069 & $0.297-0.723$ & $0.482-0.514$ \\
\hline $\mathrm{pH}$ & $7.15-7.79$ & $7.59-7.78$ & 7.78 & $7.37-7.80$ & $7.23-8.21$ \\
\hline
\end{tabular}

Data obtained was compared to a reference standard for class II lake water quality criteria (WQC), namely water for water recreation facilities/infrastructure, freshwater fish cultivation, livestock, and irrigation. These criteria are stated Number 22/2021 concerning the Management of Water Quality and Water Pollution Control (Supriyadi et al., 2015). Analysis of variance (ANOVA) was used to compare between sampling time and locations at a confidence level of $95 \%$ or an error level of 5\% (0.05). A principal component analysis (PCA) of quantitative variables of Physico-chemical was used to see the distribution based on the observed lakes. The results of the component analysis will show the correlation between the parameters at each observed lake. The lake's Trophic State Index (TSI) was calculated according to Carlson and Simpson (1996). Government Regulation number 22/2021 for class II water quality criteria (WQC)

\section{RESULTS AND DISCUSSION}

\section{Physical-chemical properties}

The physical-chemical properties of observed lakes are presented in Table 2. The temperature in all observed lakes showed a tropical condition with the range from $20.0-33.5{ }^{\circ} \mathrm{C}$. The lower temperature was recorded in Lake Telaga Warna, located the Upstream of the Ciliwung watershed (1.097-1.400 above sea level). On the other hand, the higher conductivity was recorded in Lake Sunter and Lake Cincin with 0.456 - 0.695 $\mathrm{mS} . \mathrm{cm}^{-1}$ and $0.753-0.772 \mathrm{mS} . \mathrm{cm}^{-1}$, respectively. 


\begin{tabular}{lccccc}
\hline \multicolumn{1}{c}{ Parameters } & T. Warna & Cikaret & Cilodong & Sunter & Cincin \\
\hline DO $\left(\mathrm{mg} . \mathrm{L}^{-1}\right)$ & $7.33-7.44$ & $4.4 .6-7.84$ & 9.36 & $1.48-7.13$ & $0.20-7.91$ \\
Salinity $(\mathrm{Ppt})$ & 0 & 0 & $0.00-0.09$ & 0.2 & $0.1-0.9$ \\
COD $\left(\mathrm{mg} . \mathrm{L}^{-1}\right)$ & $30.8-36.3$ & $26.9-30.8$ & $22.4-32.9$ & $44.6-49.6$ & $29.0-67.9$ \\
TN $\left(\mathrm{mg} . \mathrm{L}^{-1}\right)$ & $0.209-1.164$ & $1.109-3.793$ & $2.639-3.246$ & $4.005-4.469$ & $3.980-4.203$ \\
TP $\left(\mathrm{mg} . \mathrm{L}^{-1}\right)$ & $0.010-0.016$ & $0.087-0.096$ & $0.041-0.072$ & $0.100-1.327$ & $1.066-1.722$ \\
TN:TP Ratio & $12.9-116.4$ & $4.2-43.6$ & $33.4-131.6$ & $4.1-53.6$ & $2.2-2.5$ \\
$\begin{array}{l}\text { Chlorophyll-a } \\
\left(\mu \mathrm{g} . \mathrm{L}^{-1}\right)\end{array}$ & & & & & \\
\hline
\end{tabular}

The TSS and TDS concentrations were higher in Lake Sunter and Lake Cincin with 53-84 $\mathrm{mgL}^{-}$ ${ }^{1}$ and $297-723$ mg. $L^{-1}$ for Lake Sunter, $53-66$ mg.L. $\mathrm{L}^{-1}$ and 297 - $723 \mathrm{mg} . \mathrm{L}^{-1}$ for Lake Cincin, respectively. In most lakes, TDS concentration was still average and in accordance with the standards of Government Regulation number 22/2021 for class II water quality criteria (WQC) of $1000 \mathrm{mg} . \mathrm{L}^{-1}$. In contrast, TSS concentration was not in accordance with the standards for Lakes Sunter and Lake Cincin (50 mg.L $\mathrm{L}^{-1}$ of WQC for class II ). There was a significant difference between lakes for temperature, conductivity, SS, and TDS.

The differentiation of temperature, conductivity, TDS, and TSS between lakes may be related to the condition of the surrounding area of lakes. Ciliwung River flows across the interconnected regions within the urban area of Bogor, Depok, and Jakarta. A build dominates the land cover of the Ciliwung watershed upland and a small portion of forest located at the upper watershed or around Lake Telaga Warna.

The Higher conductivity, TSS, and TDS in Lake Sunter and Lake Cincin indicate high dissolved ions concentration. The higher TDS in those two lakes could be related to the higher input of ions from the watershed. Agriculture, domestic, and industry activities are the source of TDS materials that can add any ion and increase TDS in waters (Bhateria and Jaain, 2016; Rusydi, 2018) Higher TDS and conductivity could also be related to salinity (Rusydi, 2018). TDS value for freshwater lakes ranges from 50 to $250 \mathrm{mgL}^{-1}$ (Bhateria and Jain, 2016).

$\mathrm{pH}$ was recorded with a typical value for natural freshwater (7.15 -8.21). DO concentration showed a wide range, especially in Lake Sunter and Cincin. Lowest DO was recorded in Lake Cincin $\left(0.2 \mathrm{mg} \cdot \mathrm{L}^{-1}\right)$. The $\mathrm{pH}$ in the most lake was still normal and in accordance with the standards of Government Regulation number 22/2021 for class II WQC of 6-9. While DO concentration values in Lake Sunter and Lake Cincin were not in accordance with the standards for class II water WQC of $3 \mathrm{mg} \cdot \mathrm{L}^{-1}$.

A wide range of DO in Lake Sunter, Lake Cincin could be related to the hypereutrophic condition of lakes. In a productive or hypereutrophic lake, respiration of decomposers may remove the oxygen from the water overlying the sediment (Osbome, 2005). In shallow lakes such as Lake Sunter and Lake Cincin, windy conditions, cause water mixing, and subsequently, the low DO in the bottom layer may ascend to the upper water column.

COD describes the total amount of oxygen needed to oxidize organic matter chemically. COD value in most lakes was not in accordance with the standards of Government Regulation number 22/2021 for class II WQC of $25 \mathrm{mg} . \mathrm{L}^{-1}$. The range value in lakes are $22.5-68.0 \mathrm{mg} . \mathrm{L}^{-1}$. The highest COD concentration was obtained in lakes at the downstream area. The downstream area was a densely populated area that contributed high pollution and accumulated pollution from upstream and middle of Ciliwung watershed. Decomposition of organic matter needs oxygen, hence if DO value decreases then the value of COD increases. COD will affect the dissolved oxygen as it is representing the amount of oxygen needed chemically by microorganism to decompose organic material in the water.

In terms of nutrients such as $\mathrm{TN}$ and $\mathrm{TP}$ are also showed a gradient distribution based on the position of observed lakes in the Ciliwung 
watershed. A lower concentration of nutrient (TP) $\left(0.010-0.016 \mathrm{mg} . \mathrm{L}^{-1}\right)$ was found in the lake located at upper stream watershed or Lake Telaga Warna and a higher nutrient concentration of TP (0.100 - $1.327 \mathrm{mg} . \mathrm{L}^{-1}$ and 1.066 - $\left.1.722 \mathrm{mg} . \mathrm{L}^{-1}\right)$ was found in Lake Sunter and Lake Cincin. A lower concentration of TN was also found in Lake Telaga Warna (0.209 - $\left.1.164 \mathrm{mg} . \mathrm{L}^{-1}\right)$ and high concentration was found in Lake Sunter and Lake Cincin $\left(5.362\right.$ - $5.441 \mathrm{mg} . \mathrm{L}^{-1}$ and 2.639 - 4.469 mg. $\left.\mathrm{L}^{-1}\right)$. TP concentration in lower Ciliwung watershed (Lake Sunter and Lake Cincin) was not in accordance with the standards of Government Regulation number 22/2021 for class II WQC of $0.2 \mathrm{mg} . \mathrm{L}^{-1}$

$\mathrm{TN}$ and TP ratio is most often used as an indicator of cyanobacteria bloom and which one of the nutrients has to be controlled in order to reduce algae bloom. In Lake Maninjau bloom of Microcystis aeruginosa was occurred in the higher total phosphorus with the TN:TP ratio value 4.7 (Sulastri et al., 2019). A low TN: TP ratio in Lake Cincin indicate a surplus of phosphorus and nitrogen as limiting factor for phytoplankton growth. Therefore, phosphorus could be a major cause of eutrophication and stimulate algae bloom. As reported, phosphate concentration in lakes ranges from 0.03 to $0.1 \mathrm{mg} \mathrm{L}^{-1}$ or higher will likely promote algae blooms (WHO, 2002).

Lower chlorophyll- $a$ (13.3 - $\left.13.5 \mu \mathrm{g} . \mathrm{L}^{-1}\right)$ was found in the lake located at the upper stream of watershed or Lake Telaga Warna and higher chlorophyll- $a$ concentration (126.1 - $430.9 \mu \mathrm{g} . \mathrm{L}^{-1}$ and $20.1-365.4 \mu \mathrm{g} . \mathrm{L}^{-1}$ ) was found in the lower part of watershed or Lake Sunter and Lake Cincin. Standard value Chlorophyll- $a$ and total phosphorus for eutrophic lake range from $7.3-20$ $\mu \mathrm{g} . \mathrm{L}^{-1}$ and $24-48 \mu \mathrm{g} . . \mathrm{L}^{-1}$ and for hypereutrophic range from 56-55 $\mu \mathrm{g} . \mathrm{L}^{-1}$ and $96-192 \mu \mathrm{g} . \mathrm{L}^{-1}$ (Carlson and Simpson, 1996). It indicates the trophic status of observed lake eutrophic to hypereutrophic. In most lakes, TN/TP value $>12$ showed phosphorus is a limiting nutrient for algae growth except Lake Cincin, TN/ TP ratio value < 12 showed nitrogen is a limiting nutrient for algae growth (Jorgensen, 1980). Based on ANAVA test, in most locations, values of TDS, $\mathrm{pH}, \mathrm{DO}, \mathrm{COD}$, $\mathrm{TN}$, TP, and chlorophyll-a were not show a significant difference $(\mathrm{P}>0.05)$.
Mostly chlorophyll- $a$ concentration showed a high in observed lakes which is the highest concentration $\left(431 \mu \mathrm{gL}^{-1}\right)$ recorded in Lake Sunter. In lake Maninjau, chlorophyll- $a$ concentration reached $97.475{\mu \mathrm{gL}^{-1}}$ during Microystis aeruginasa bloom in April 2018 (Sulastri et al, 2019). WHO has defined Chlorophyll- $a$ of 10 $\mu \mathrm{gL}^{-1}$ as a threshold effect for drinking water and chlorophyll- $a$ of $50 \mu \mathrm{gL}^{-1}$ as a threshold effect for recreational water use (Ho and Michalak, 2015). Chlorophyll- $a$ of $10 \mu \mathrm{gL}^{-1}$ has a potential effect on skin irritation or allergenic effects, and $50 \mu \mathrm{gL}^{-1}$ for increased probability of irritative symptoms and toxic impacts, both under conditions of cyanobacterial dominance (Falconer et al., 1999).

Principle component analysis showed there are two groups of lakes based on the characteristic of water quality conditions (Figure 2). The first group is Lake Telaga Warna, Lake Cikaret and Lake Cilodong characterized by higher of water depth and Secchi depth. The second group (Lake Sunter and Lake Cincin) ares characterized by higher of conductivity, TDS, salinity, COD, TP, and chlorophyll-a.

Lake Sunter and Lake Cincin located in Jakarta City was characterized by conductivity, TDS, TSS, $\mathrm{TN}$, TP, and Chlorophyll- $a$. The water quality condition of those two lakes could be affected by the crowded urban area of Jakarta City and the accumulation of pollution materials coming from the upper river system. Land use at the catchment basin affects the water chemistry of a lake therefore lakes in an urban area typically show an elevated level of nitrate and phosphate in waters which support productivity (Sulastri et al., 2008). The primary sources of nutrient input are runoff, erosion, and leaching from fertilized agricultural areas, sewage from cities, and industrial wastewater (WHO, 2002). 


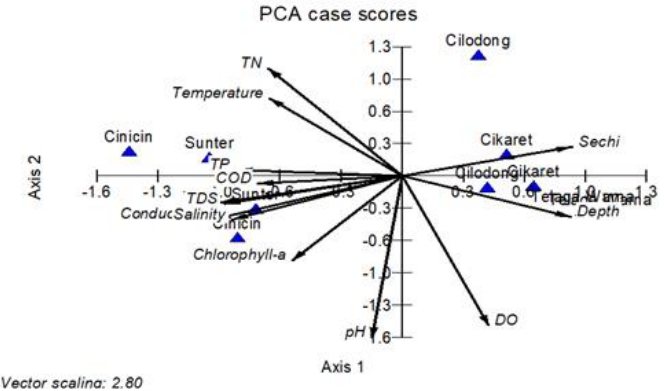

Figure 2. Principle Component Analysis (PCA) of Lake Telaga Warna, Lake Cikaret, Lake Cilodong, Lake Sunter, Lake Cincin, based on the depth, Secchi depth, temperature (Temp) DO, pH, COD, Conductivity (Condt), TDS, TSS, Salinity, TN, TP parameters

\section{Trophic Status}

Based on Carlson'Trophic Status Index (TSI) calculation, Lake Telaga Warna Lake Cikaret, and Lake Cilodong were classified as eutrophic while lake Sunter and Lake Cincin were classified as hypereutrophic lake (Figure 3). The relationship between TSI variables shows that in Telaga Warna $\mathrm{TSI}(\mathrm{SD})=\mathrm{TSI}(\mathrm{Chl}-a)>\mathrm{TSI}(\mathrm{TP})$ indicate Phosphorus limits algal biomass (TN/TP > 33:1). In Lake Cilodong TSI $(\mathrm{SD})=\mathrm{TSI}(\mathrm{Chl}-\mathrm{a})=\mathrm{TSI}(\mathrm{TP})$ indicates algae dominate light attenuation; TN/TP 33:1. Lake Cikaret, Lake Sunter, and Lake Cincin TSI(Chl-a) > TSI(SD) indicated large particulates, such as Aphanizomenon flakes dominate (Carlson, 1983 in Maraşlığlu F \& Gönülo, 2014).

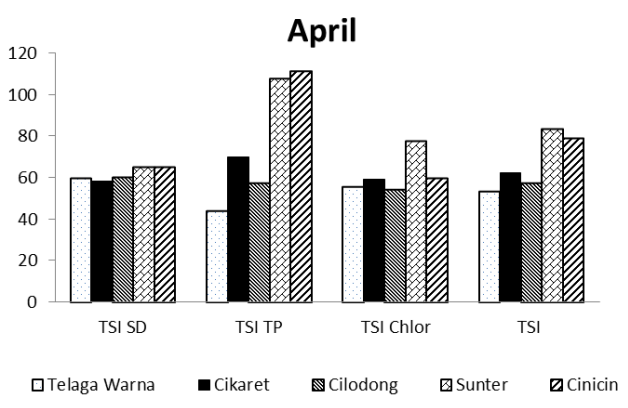

(a) April

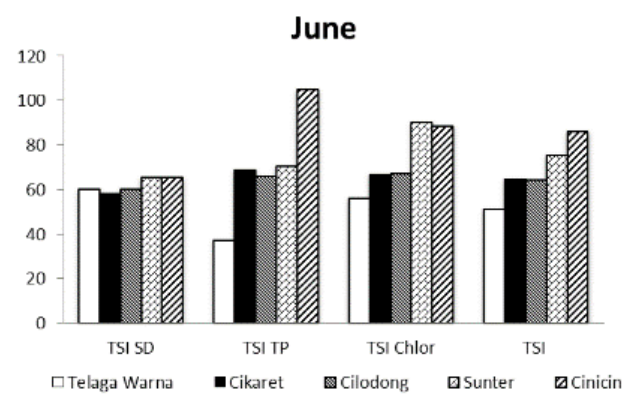

(b) June

Figure 3. Trophic State Index (TSI) of observed lakes (a) April and (b) June

\section{CONCLUSION}

The concentration of some Physico-chemical parameters in small lakes at the Ciliwung watershed tended to increase downstream, decreasing oxygen concentration. There are two groups of lakes based on water quality and trophic status. Lakes are located at the lower watershed, including Lake Sunter and Lake Cincin, tended to characterize by higher nutrient and organic substances concentrations. . Based on TSI value, lakes at the upper and the middle downstream (Telaga Warna lakes, Cikaret lakes, and Cilodong lakes) are characterized as eutrophic lakes. Lake Sunter and Lake Cincin are characterized as hypereutrophic lakesThe downstream area was a densely populated area that contributed high pollution and accumulated pollution from upstream and middle of Ciliwung watershed.

\section{ACKNOWLEDGEMENTS}

The authors are grateful to the Coremap-CTI program, Deputy For Earth, Indonesian Institute of Sciences (LIPI), for the provision of financial support towards this study. Colleagues who have assisted with activities in the field and analysis in the laboratory.

\section{REFERENCES}

Bhateria R, Jain D. 2016. Water quality assessment of lake water: a review Sustainable Water Resources Management volume 2, pages161-173 (2016)

Carlson R E, Simpson J. 1996. A coordinator's guide to volunteer lake monitoring methods. 
North American Lake Management Society. 96 pp.

Chorus I, Falconer IR, Salas HJ, Bartram J. 2000. Health risks caused by freshwater cyanobacteria in recreational waters. $J$ Toxicol Environ Health $B$ Crit Rev Oct-Dec 2000;3(4):323-47.

DOI: $10.1080 / 109374000436364$

Department of Public Work of DKI Directorate of water Resources, River and Lake. 2010. Document of Environmental Impact Analysis related to Environmental Management Plant and Environmental Monitoring Plant.

Dokulil, M. T. and K. Teubner. 2011. Eutrophication and Climate Change: Present situation and Future Scenarios in EUTROPHICATION: Causes, Consequence, and Control (A. A. Ansari, S. Singh Gill, G. R. Lanza, W. Rast: Eds), Springer Science Business Media BV.

Falconer, I., Bartram, J., Chorus, I., KuiperGoodman, T., Utkilen, H., Burch, M. and Codd, G.A. (1999) Safe levels and practices, in I. Chorus and J. Bartram (eds.), Toxic Cyanobacteria in Water: a Guide to their Public Health Consequences, Monitoring and Management, Spon, London, United Kingdom, pp. 155-178.

Henny C, Meutia A A. 2014. Urban lakes in megacity Jakarta: risk and management plan for future sustainability. Procedia Environmental Sciences 20:737-746 https://doi.org/10.1016/j.proenv.2014.03.088

Henny C, Meutia AA. 2014. Henny C, Meutia AA. 2014. Water Quality and Quantity Issues of Urban Lakes in Megacity Jakarta. LIMNOTEK Perairan Darat Tropis di Indonesia 21(2): $145-15$

Ho JC, Michalak AM. 2015. Challenges in tracking harmful algal blooms: A synthesis of evidence from Lake Erie. J. Great Lakes Res. 41 , 317-325. https://doi.org/10.1016/j.jglr.2015.01.001

Hwang S. 2020. Eutrophication and the Ecological Health Risk. Int. J. Environ.
Research and . Public Health 17, 6332 ; https://doi.org/10.3390/ijerph17176332

Jøgensen SE. 1980. Lake Management, Pergamon Press Ltd. Oxford-Great Britain,167 pp.

Ladwig R, Furusato E, Kirillin G, Hinkelmann R. 2018. Water 10,186 doi;10.3390/w10020186

Maraşlıŏlu F \& Arif Gönülol, 2014. Phytoplankton Community, Functional Classification and Trophic State Indices of Yedikır Dam Lake (Amasya). J. BIOL. ENVIRON. SCI., 8(24), 133-141

Nesseli-Flores J 2008 Urban Lake: Ecosystem at Risk, Worthy of the Best Care Proceeding of Taal 2007 12th World Lake Conference: 13331337

Osborne PL. 2005. Eutrophication of shallow tropical lake. In: The Lake Handbook: Restoration and Rehabilitation. PE O'Sulivane \& CS Reynolds (Eds). (2): 299 pp. ISBN : $\underline{063204795 X}$

Prihantini, N. Betawati, W. Wardhana, D. Hendrayanti, A. Widtawan, Y. Aryani, \& R. Rianto, 2008. Biodiversity of Cyanobacteria at Several Lakes in Jakarta, Depok and Bogor. MAKARA SAINS. 2(1): 44- 54

Rusydi AF. 2018. Correlation between conductivity and total dissolved solid in various type of water: A review. IOP Conf. Series: Earth and Environmental Science 118 (2018) 012019

Sinha E, Michalak AM, Balaji V. 2017. Eutrophication will increase during the $21 \mathrm{st}$ century as a result of precipitation changes. Science Vol. 357, Issue 6349, pp. 405-408 DOI: $10.1126 /$ science.aan 2409

Wakhid W, Krisanti M, Rauf A, Sumertajaya I M. 2020. Aquatic insect assemblages in four urban lakes of Bogor, West Java, Indonesia. Biodiversitas Journal of Biological Diversity 21(7):3047-3056.

World Health Organisation. 2002. Eutrophication and Health. European Commission, Luxembourg.128pp. ISBN 92-894-4413-4 
Yu D, Xie P, Zeng C, Xie L, Chen J. 2016. Yu D, Xie P, Zeng C, Xie L, Chen J. 2016. Ecological Engineering. Ecological Engineering, 87, 246253

https://doi.org/10.1016/j.ecoleng.2015.11.039

Sulastri. (2002). Spatial and temporal distribution of phytoplankton in Lake Maninjau, West Sumatra. Proceeding of the International Symposium on Land Management and Biodiversity in South East Asia. (pp. 403-408). Bali, Indonesia.

Sulastri, Harsono E K, Suryono $\mathrm{T}$ and Ridwansyah I 2008 Land Use, Water Quality, and Phytoplankton Structure Community in Some Small Lakes West Jawa Oseanologi dan Limnologi di Indonesia (OLDI) 34(2): 307322

Sulastri, Henny C, Arianto AB. 2019. Phytoplankton Composition and The Occurrence of Cyanobacterial Bloom in Lake Maninjau, Indonesia. IOP Conf. Series: Earth and Environmental Science 380 (2019) 012020.

Supriyadi A, Syaufina L, Iin Ichwandi I. 2015. Ealuasi Kebijakan Pengelolaan Situ Cikaret, Kabupaten Bogor. LIMNOTEK, 22 (1): 52-63 [in Indonesian] 